\title{
Elm, Lime and Middle Neolithic Cultivation - an Interesting Problem
}

\author{
Hans Göransson
}

\begin{abstract}
This article deals with the interpretation of a pollen diagram close to the Alvastra piledwelling. Ostergötland. The traditional view of a regression in human activity during the Middle Neolithic is questioned and an alternative view is put forward.
\end{abstract}

Hans Goransson. Department of Quatemary Geology. Tornav. I3. S-22363 Lund, Sweden.

As this first edition of CSA deals with "problems" I find it appropriate to present a pollen diagram section from the Dags mosse bog. This bog is situated in the westernmost part of the province of Östergötland, between the hill Omberg and Lake Tåkern. The Alvastra spring mire borders on the southern part of the Dags mosse bog. In this spring mire the Alvastra pile-dwelling is situated.

The archaeologists have demonstrated that the Alvastra pile-dwelling was a community center - a cult site - in a rich countryside. The size of the population in this community was probably about 130 persons who lived around - or in the vicinity of - the Dags mosse bog (for archaeological references; see Browall 1986).

Very many carbonized grains of barley and emmer wheat have been found in the occupation layer of the Alvastra pile-dwelling. Carbonized seeds of weeds from arable land such as, for instance. Artemisia vulgaris and Polygonum convolvulus have been recorded. Bones of cattle and sheep have been found in the occupation layer (During 1986). Thus during "Alvastra time" arable lands existed on high ground and grazed areas occurred both on high and wet ground.

We know exactly where the level which corresponds to "Alvastra time" is to be placed in the Dags mosse diagram. Astonishingly not a single cereal pollen grain is recorded at this level and the grazing activities are ex- tremely difficult to trace in the pollen diagram (no Plantago lanceolata present). Instead we observe a regeneration of elm and lime and a strong decline of birch at the "Alvastra time" level (= 4450 B.P). According to tradition, this should disclose that the Early Neolithic "expansion" had ended and that the Middle Neolithic "regression" had begun. If the Alvastra pile-dwelling had not been discovered (by chance!) then we would have believed in this "regression" hypothesis.

The pollen diagram from the Dags mosse bog thus resembles many - or most! - other diagrams from southern Sweden. First an elm decline which everywhere has a C14-age of $\mathrm{c}$. 5150 B.P. $(\mathrm{T} 1 / 2=5568)$. Also lime (Tilia) declines at this level as does ash (Fraxinus) where this species has high values (as, for instance, in Scania). Above the elm decline level birch (Betula) rises strongly. This c. 650 C14-year long period with low values for elm, lime and ash and high values for birch reflects - according to tradition - the Early Neolithic "expansion phase". Then comes the Middle Neolithic "regression phase", which is characterized by a decline of birch and an increase of elm, lime and ash.

The diagram from the Dags mosse bog discloses that the increase of elm and lime $\mathrm{c}$. $700 \mathrm{Cl}$ 4-years after the elm decline does not reflect a regression of cultivation of cereals or of grazing activities - the occupation layer from the pile-dwelling shows the opposite 


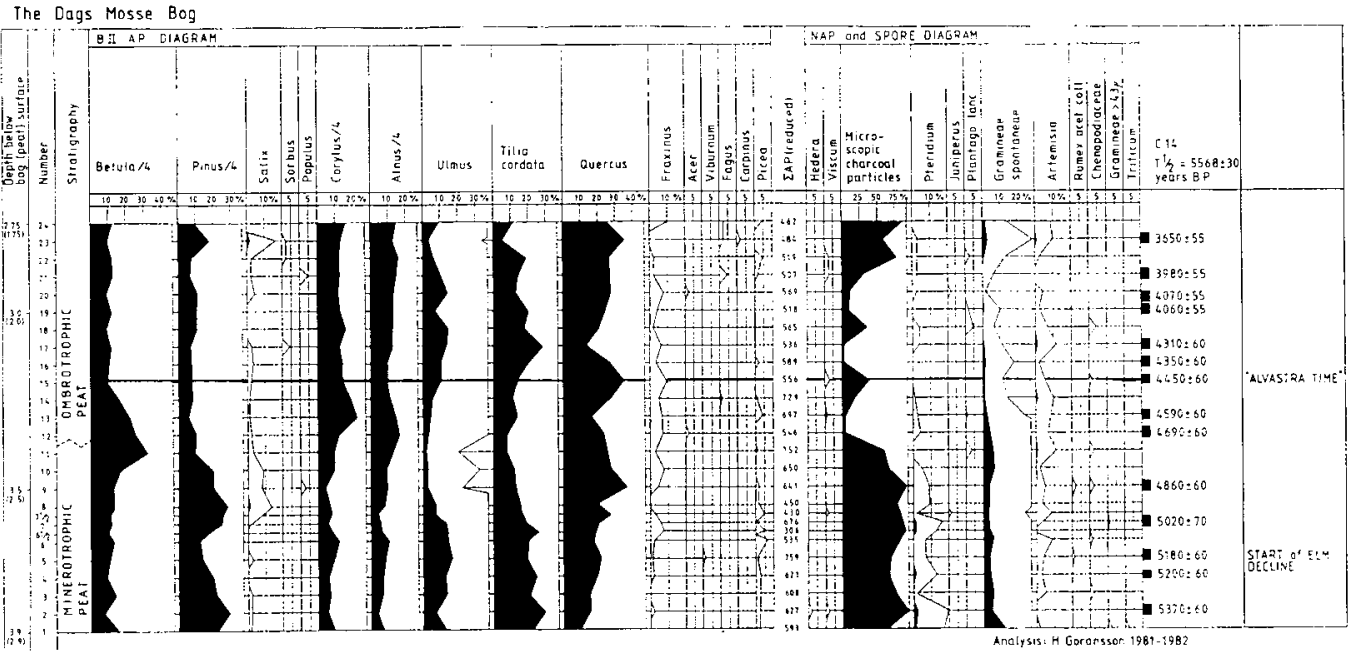

The pollen diagram from the Dags mosse bog. "Alvastra time" (= "Alvastra pile-dwelling time") is marked br a line.

(Göransson 1987, 1991). Thus it is not necessary to assume that other pollen diagrams from southern Sweden reflect a regression of agriculture at the level where elm and lime (and ash) regenerate after the elm decline.

It is, indeed, a problem that we are so attached to tradition that we still believe that high values of elm and lime reflect an absence - or decline - of agriculture.

English revised by Laura Wrang.

\section{REFERENCES}

Browall, H. 1986. Alvastra pälbuggnad: social och ekonomiskbas. Theses and Papers in North-European Archaeology 15. Stockholm.

During. E. 1986. The Fana of Alvasira. An Osteological Analysis of Animal Bones from a Neolithic Pile Dwelling. Stockholm Studies in Archaeology 6.

Göransson, H. 1987. Neolithic Man and the Forest
Environment around Alvastra Pile Dwelling. Theses and Papers in North-European Archaeology 20. Stockholm.

- 1991. Vegetation and man aromind Lake Bjarsjöholmssjön during prehistoric time. Lundqua Report 31. Lund 